\title{
Disaster Resilient Construction of Water Spouts in Kathmandu Valley of Nepal
}

\author{
Rajesh Shrestha*, Khet Raj Dahal \\ Email address: \\ rajeshshrestha402@gmail.com (R. Shrestha),krdahal@liast.edu.np (K. R. Dahal) \\ ${ }^{*}$ Corresponding author
}

Department of Disaster Risk Engineering and Management, Lumbini International Academy of Science and Technology, Lalitpur, Nepal

\section{To cite this article:}

Rajesh Shrestha, Khet Raj Dahal. Disaster Resilient Construction of Water Spouts in Kathmandu Valley of Nepal. Journal of Civil, Construction and Environmental Engineering. Vol. 5, No. 4, 2020, pp. 72-83. doi: 10.11648/j.jccee.20200504.12

Received: July 18, 2020; Accepted: August 11, 2020; Published: August 18, 2020

\begin{abstract}
The Kathmandu valley was formed by draining the lake through Bagmati River of the Chobar gorge in the ancient time. The bedrock inside the surface of Kathmandu valley consists of clay sediment i.e Kalimati (It means the black soil in Nepali) clay which is also called the dense impenetrable black mud. This type of soil is very fertile. The people of the valley utilized the geographic structure and the natural resources with skill to enhance civilization, which is shown from the traditional water supply or the hiti (Dhunge Dhara in Nepali) system. It is also called the water spout or rainspout. This study was conducted during the period from January to June 2020. Published literature such as paper, manuals, reports, and database were collected from different sources and went on thoroughly. The study found that the population of Kathmandu and Lalitpur is increasing rapidly but the source of drinking water is decreasing gradually. In the past, Dhunge Dhara was feeding the communities for drinking water as there are all together 237 Dhunge Dhara in Kathmandu and Lalitpur area. In the Kathmandu Valley, the source of water spouts decline is due to the development of various engineering infrastructures such as roads, buildings, towers, and so on. Similarly, rapid growth of urbanization took place near the source of water spouts. As a result, there could not be the chance of ground water recharge. The water from the rainfall flows directly through the waste pipe to the river. In the past, there were irrigation canals called Rajkulo (Canal made by the King in the Kathmandu Valley), these canals effectively recharged the ground water. As the valley is converted into the city of concrete, it causes stoppage of ground water recharge near the hiti. Consequently, there is no water in the water spouts i.e. in Dhunge Dhara. The study would like to suggest that the traditional Dhunge Dhara in the valley must be preserved through the initiation of the local, provincial and central government.
\end{abstract}

Keywords: Dhunge Dhara, Rajkulo, Ground Water Recharge, Water Law and Policies

\section{Introduction}

Water is very essential element for the survival of life which plays very important role in our daily life. We live in the earth which contains about $2.5 \%$ of fresh water. The water in our earth is always in moving condition, it is the natural process which is also called the water cycle or the hydrological cycle which describe the movement of water on, above and below the surface of land continuously. Further it describes the atmosphere of our earth contains the full of water. About $90 \%$ of water is produced by evaporation from water bodies where as $10 \%$ produces from transpiration process of plants. Cloud is the source of atmospheric water. The volume of water $\left(\mathrm{V}_{\mathrm{w}}\right)$ in the atmosphere is about 12900 $\mathrm{km}^{3}$ which is nearly about $0.001 \%$ of the total volume of water on Earth according to National Oceanic and Atmospheric Administration [1].

The soft water falling from the atmosphere which containing soluble mineral matter is called the rainwater. It is extremely clean and safe water on earth [2]. In the past 1960s, there were enough source of water no any shortage in mountain valleys, wells and pumps, all were always accessible. But now days, the bottled water is considered as the pure form of water which is actually comes from the rainwater. All the water from taps, wells, rivers or lake water is generated from rain water. The rain water falls from the sky soaks in to the ground in the form of mineral water which is called ground water, the safe source for drinking. If it falls 
in waste, then it is called waste water which flow through river to the sea. Rain water can prevent from flooding and droughts, reducing the river pollution and prevent groundwater also reduce heat island effect to the cities [3].

The Kathmandu valley was formed by draining the lake through Bagmati River of the Chobar gorge in ancient time. The bedrock inside the surface of Kathmandu valley consists of clay sediment i.e. kalimati clay which is also called the dense impenetrable black mud which is very fertile. The people of the valley utilized the geographic structure and the natural resources with skill to enhance civilization which is shown from the traditional water supply or the hiti (Dhunge Dhara in Nepali) system in English it is also called the water spout or rainspout. Nepal is the country where we found various types of water architecture among them the hiti is the most elaborate and complex in design and technology. The rajkulo, wells and ponds are the main source of water for the hiti along with the ghats (riverside cremation sites) and jahdu (water tank for drinking). These hiti and rajkulo are the traditional water supply in this valley which is started in Licchavi period and further developed in the Malla period [4]. For the irrigation in the paddy field of village, the rajkulo was build whereas the hiti is formed to facilitate drinking water in the city which is also associated with the special festivals and rituals. These systems survived in Lalitpur due to the strong local communities as they have urgent need for water, whereas in Kathmandu it is almost in lost condition [5].

\section{Problems in the Water Spouts}

The Kathmandu valley is the historically important valley of Nepal. It is also called the Nepa valley which has at list 130 important sites of historical importance including pilgrimage sites for Hindus and Buddhists. It is highly developed and population of about roughly 1.5 million people in Nepal including Lalitpur, Kirtipur, Madhyapur Thimi and Bhaktapur. In Kathmandu and Lalitpur only there are 153 working natural water resources along with 38 are not working and 40 are not exists [6]. There are two major Rajkulos which supply the water to Lalitpur and Kathmandu. The main sources of these Rajkulos is the upstream of Tikabhairab which channels water from Lele and Naldu rivers [7]. The most of the hitis in the Lalitpur are source of water for urban poor only. The large number of farmers still depends upon the rainwater for irrigation in the land. The main source of the hitis is the underground springs located around it linked through underground supply and drainage system which use the natural sand filters system to purify the water. The surface of the valley contains the dense black mud bedrock which prevents the access to very deep underground water hence ponds network constructed at particular locations to accumulate rainwater and recharge the shallow aquifers [8].

The municipal water supply system is unable to provide access of drinking water to urban area. The most of the people still depends on traditional water supply systems like hitis, wells etc. The unplanned building construction and construction of modern underground structure caused the rajkulo being damaged and also affect the ancient system which affects the loss of ponds that help to recharge the hitis. The water spouts start decreasing rapidly and the pond which is induced by Rajkulo becomes polluted in Kathmandu and Lalitpur area [9]. Most of the hitis in the Kathmandu are declined even not in used due to the rapid undergoing construction project. The sources of drinking water used in these municipalities are Public water supply, well, springs and stream water. It has lack of treatment facilities for waste water and faecal sludge. At last, the waste water discharges through Bagmati River. The water quality of Bagmati River found to be more organic pollutants and the drinking water status of Kathmandu is found to be poor quality as it contains E-Coil with less $\mathrm{Mg}$ but the $\mathrm{PH}$ value is maintained [9]. Most of the people in the Lalitpur area depend on pond water and hitis; we do not know the degree of pollution in that source of water. Nowadays the populations of the world increasing day by day. Due to which the urbanization, water pollution and deforestation also increase rapidly which induced to the decrease the world's fresh water resources. The world health organization concludes that about 900 million people lack of safe drinking water, 2.5 billion people lack of proper sanitation, millions of people die due to water related disease and billions of dollar losses due to water related disaster. Disaster resilience is the preparedness of individuals, social communities, organizations and states to adjust and recuperate from hazards and shocks. It determined the degree of capability of organizing themselves to learn from past disasters and help to reduce the risks for future [10].

Kathmandu Valley is divided by eight rivers in which Bagmati is the main river of the valley. The Bishnumati, Dhobi khola, Manohara Khola (River), Hanumante khola and Tukucha Khola are the element of it. These rivers are originated from the mountains in the elevation range of 1500 to 3000 meters. Kathmandu Valley has the area of $899 \mathrm{~km}^{2}$ and population density of about $2793 / \mathrm{km}^{2}$. There are five major climatic regions found in Nepal among them Kathmandu lies in the warm Temperature zone. The highest rainfall recorded in Kathmandu valley is about $1400 \mathrm{~mm}$ with the humidity of $75 \%$ [11].

Lalitpur is the third largest city of Nepal after Kathmandu and Pokhara which is also called Pätan, Yala and Manigal, the best known for its rich cultural heritage. It has total area of $15.43 \mathrm{~km}^{2}$ and population of about 468,132 . It is also called the city of fine arts. It consists of large number of sacred building, temples, pagodas, Stupas and Shikhras, monasteries, math and Chaitya. The Patan Durbar Square is one of the seven Heritage site in the Kathmandu Valley. From recent survey, it is found that maximum $33 \%$ of water demand fulfills by NWSC-supply, $7 \%$ fulfill by private well, $3 \%$ fulfills by neighbors well, $10 \%$ fulfills by public well $10 \%$ fulfills by tanker supply, 3\% fulfills by rain water and $7 \%$ fulfills by NWSC-Collection tank and $27 \%$ water demand fulfills by traditional stone spouts. There are 176 Stone Spouts were built in Kathmandu, 61 in Lalitpur and 152 in Bhaktapur Districts of Kathmandu Valley. Thus, there are all together 389 Stone Spouts found in Kathmandu valley [12]. 


\section{Definition and History of Hitis (Dhunge Dhara)}

Hiti is also called Dhunge Dhara in Nepali and Stone spout in English which is made of stone and a channelized spout of water serving as tap with a shrine attached to it. It is designed in symmetrical manner and made to appear from a vertical wall. It exists in Kathmandu Valley since $15^{\text {th }}$ centuries [13]. These hitis are simply systematized and give them artistic shape by the Lichhavi (The frmer rullrs of Kathmandu). However, its morphology as exits from the Lichhavi period remains the same but its name has been changed with the time. In that time these Dhunge Dhara is also called Kirti which means the merit. Those who build a Dhara (spouts), as a custom, receive merit as the drinking water is one of the most important goods for human life. There are about $95 \%$ of Dhunge Dhara concentrated in this valley. From the survey data of the Kathmandu Town Development project there are 117 Dhunge Dhara in 1982. There are 40 such Dhunge Dhara in Patan and about $80 \%$ of them are still functioning. Similarly, 103 such Dhunge Dhara in Bhaktapur also. Among them most of Dhunge Dhara were constructed in the medieval period [13].

The main sources of hitis are Rajkulos (Canals), built by the Malla king. It starts from the foothills and fed water to spouts situated in various part of urban area of Bhaktapur and Lalitpur. These Rajkulos are still exists in nature. Some hitis have their own independent source of water. These hitis accumulate the underground water which is percolated from the surface during rain. Most of the hitis are made from stone, but inside the Royal Palaces of Kathmandu, Patan and Bhaktapur of the medieval period are of gold plated ones, which are building by Royal Patronages for example Sundhara of Kathmandu, Patan and Bhaktapur [14]. The hitis available in Katmandu Valley are in different shape and size but most of them are square or rectangular shape. Sundhara is the largest one among the other Dhunge Dhara and the best example of its kind constructed during the Shah period. The Manga hiti is the oldest hiti dated at 570A. D. From the view point of craftsmanship Tusha hiti is richly decorated by 72 stone sculptures, which was built by King Siddhi Narsing Malla of Patan. Similarly, the Mohan Kali hiti has 40 images of different Gods built by King Pratap Malla in 1652 A. D. [14].

\subsection{Source of Water for Dhunge Dhara}

A Dhunge Dhara or hiti is the traditional stone drinking water fountain. It is a complicated carved stone waterway through which water flows uninterrupted from underground sources. It is the part of traditional drinking water supply in Kathmandu valley. It is supported by ponds, canals (Rajkulo) and rain water for continuous supply of drinking water from it.

\subsubsection{Rajkulo (The Royal Canals)}

The Dhunge Dhara is recharged not only by rain water but also by the royal canals. The royal canals used to bring water from the stream, spring or pond from foothill to the artificial ponds for the Dhunge Dhara [15]. In 1678, The Malla King constructed the state canal to feed stone spouts located in Bhaktapur and Patan [16]. There are three canals; Budhikanta Canal for Kathmandu, Bageswori Canal for Bhaktapur and Tikabhairab Canal for Patan. These Canals recharge the 31 ponds in the cities and also supply water for the irrigation system [17]. There are almost half of Dhunge Dhara of Bhaktapur and 51 Dhunge Dhara of Patan are run through the Royal Canals [18].

\subsubsection{Ponds}

An area filled by water is called a pond. It is either formed naturally or artificially and smaller than the lake. The ponds are also named as Pukhu in Newari and Pokhari in Nepali which were constructed as a source of water in Kathmandu valley during the Kirata Kingdom. The ponds are recharged through rain water and also from the Royal Canal too [19]. During Lichhavi Period, the pond was used for stone spouts and dug well for drinking water. In Kathmandu, Lainchour Pokhari (pond), Rani Pokhari and Ikha Pukhu (pond) are used for the spouts. In Patan, Nhu Pukhu, Paleswan Pukhu and Jyawalkhyo Pukhu are used to recharge the Dhunge Dhara. Similarly, in Bhaktapur, Siddha Pokhari, Kamal Binayak Pukhu and Nā Pukhu are used for the ground water recharge and Dhunge Dhara [20].

The ponds are inter linked with each other in some case; when one pond filled with water completely then the over flow directed towards another pond and so on. In such a way, the network of water bodies created as a source of water during dry season [21]. One time, there are all together 90 Ponds in Kathmandu valley in which 30 Ponds in Bhaktapur, 21 Ponds in Kathmandu and 39 Ponds in Patan. From the survey data of Kathmandu Valley Water Supply Management Board (KVWSMB), there are all together 233 ponds recorded in 10 municipalities of the Kathmandu Valley [22].

\subsubsection{Rainwater}

The water which is fallen as rain and collects soluble matter from a soil is called Rainwater. Normally, a lots of rain water wasted in the drain flowing from the roofs of houses and the road. The rain water conserving the ground or the surface of land and recharge the ground water and the Pond. The ponds which is use as the source of drinking water for the Dhunge Dhara, is actually filled by rainfall [23].

\subsection{Basic Architecture of a Dhunge Dhara}

Basically in the Kathmandu Valley, the Dhunge Dhara is located in the base below the street level due to the natural flow of water which is also called hitigah in Newari Bhasha. The base is designed by using stone and brick and the floor is covered by stone slabs whereas the bottom and side of base made as waterproof by coating it with a layer of special type of black mud (Kacha in Newari Bhasha) which prevents water from seeping [24]. The large majority of Hitis have one to three spouts, some have four and five spouts and some have nine, twelve, twenty-two and hundred eight spouted too. 
For example, Baise Dhara of Balaju has 22 spouts and Muktidhara in Muktinath temple has 108 spouts [25, 14].

The base of Dhunge Dhara is surrounded by a low wall which helps to keep the surface runoff out from it. The base can be reached by one or more stone stairs which depends on the depth and overall size of Dhunge Dhara. Beside stone the hiti made from other materials like copper, gold, brass and wood too. Most of them have the shape of mythical makara which is also called hitimanga. It contains the snout of a crocodile, the trunk of an elephant, tusks and ears of a wild boar and the tail of a peacock [26]. There is a shrine honoring a specific god in above the Dhunge Dhara and furnish with a sculpture of Bhagiratha below it. The filter system of Dhunge Dhara is made by using gravel, sand, lapsi (Choerospondias axillaris in English) and charcoal which can filter the water before it enters the spout [27]. There is a small pool in front of the Dhunge Dhara which collect the water flowing from it and disappears into a drain which then guided towards another spout, agricultural land for irrigation or a Pond. But some time water which is first time used is passing through several another spouts for e.g. In case of Washa hiti of Patan, the water is first passing towards Amrit Hiti, then to Dathu Hiti at last it is passing through Buincha Hiti [28]. Similarly, in some Dhunge Dharas the water from it directly drains inside a Pond for e.g. Nag Pokhari hiti of Bhaktapur, whereas there are also a Pond with spouts integrated in to their walls for example the Bhandrakhal Pokhari in Patan. Most of the Dhunge Dhara closely associated with public shelters which is also called Dharmasala. The Shelter is either separate or connected with walls of the Dhunge Dhara. As for example, Manga hiti of Patan and Bhimsen Hiti of Bhaktapur can be taken [29].

\subsection{Use of Hiti}

The Hiti is not only used for the normal household purposes but also for work as well as for religious and cultural activities in that area. It can be seen that the Hiti is used for different purpose such as drinking, cooking, and washing cloth. The most of the Dhunge Dhara is believed to have healing properties. For example, the water from the Sundhara in Kathmandu is believed to be good against arthritis [30]. The Hiti is also used as a Disaster response in case of fire in densely built city where the Fire Brigade unable to go. The Kontihiti of Patan is an example of it [31]. It is also use to relieve the thirst of the tourist.

\section{Water Policy, Law and Regulations of Nepal}

The policy related to sanitation start in 2050BS. After that the comprehensive policy lunch with both water supply and sanitation in 2055BS. The Drinking Water Regulation 2055 (1997) contains the Nepal Water Supply Sector Policy. From Water Aid Nepal, the summary of relevant Nepali Laws in Chronological order [32].

Table 1. Summary of Relevant Nepali Laws in Chronological Order.

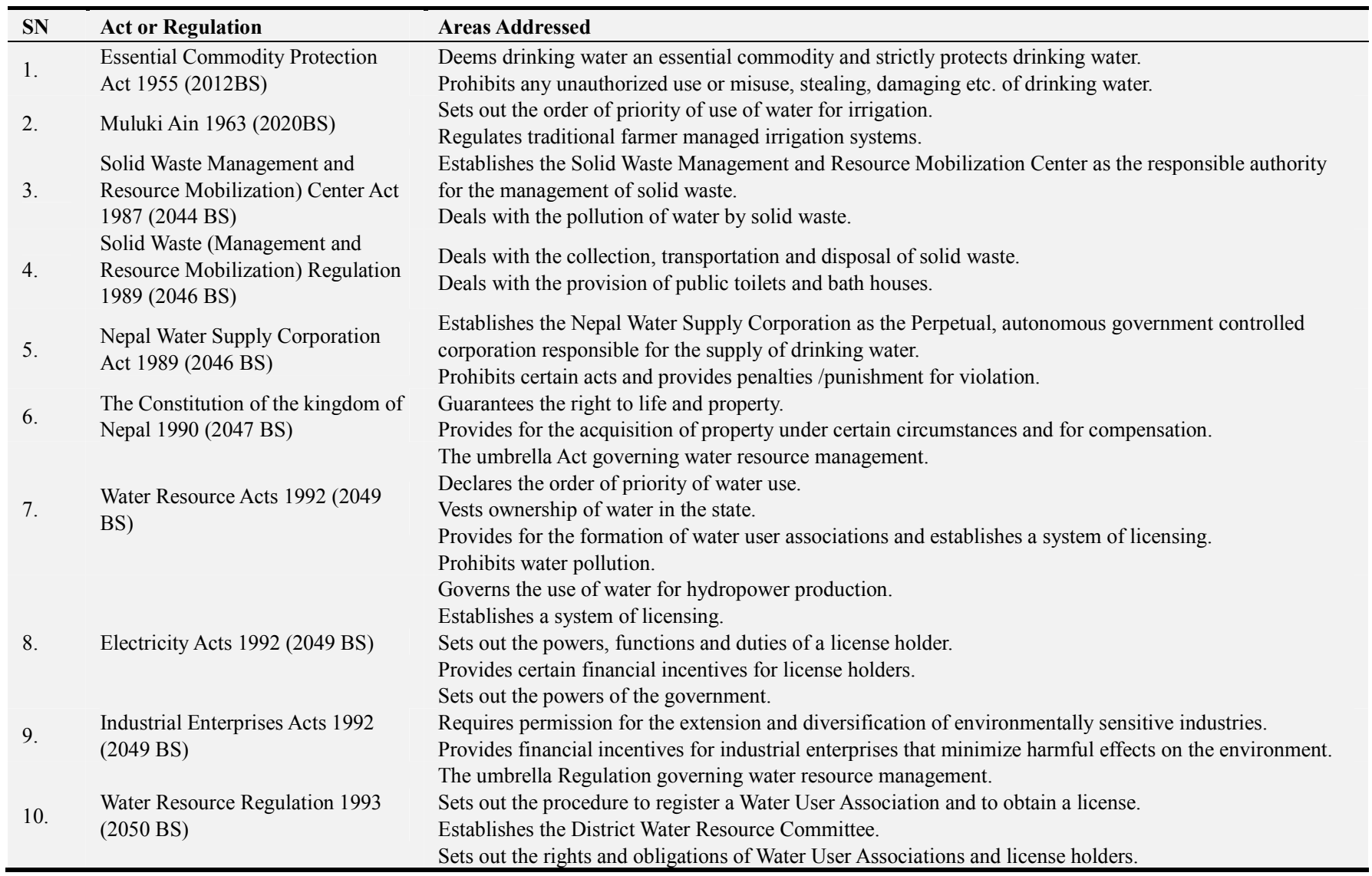




\begin{tabular}{|c|c|c|}
\hline SN & Act or Regulation & Areas Addressed \\
\hline & & Deals with the acquisition of house and land and compensation. \\
\hline 11. & $\begin{array}{l}\text { Electricity Regulation } 1993 \\
\text { (2050BS) }\end{array}$ & $\begin{array}{l}\text { Sets out the procedure for obtaining a license. } \\
\text { Deals with the acquisition of house, land and compensation. } \\
\text { Sets out the powers, functions and duties of license holders. }\end{array}$ \\
\hline 12. & $\begin{array}{l}\text { Environment Protection Act } 1996 \\
\text { (2053BS) }\end{array}$ & $\begin{array}{l}\text { Requires certain persons/bodies to conduct an EIA or IEE. } \\
\text { Deals with the prevention and control of pollution. }\end{array}$ \\
\hline 13. & $\begin{array}{l}\text { Environment Protection Regulation } \\
1997 \text { (2054BS) }\end{array}$ & $\begin{array}{l}\text { Lists the water related projects required to conduct an EIA or IEE. } \\
\text { Deals with the control of water pollution and pollution control certificate. }\end{array}$ \\
\hline 14. & $\begin{array}{l}\text { Drinking Water Regulation } 1998 \\
\text { (2055BS) }\end{array}$ & $\begin{array}{l}\text { Regulates the use of drinking water. } \\
\text { Provides for the formation of Drinking Water User Associations and sets out the procedure for registration. } \\
\text { Deals with licensing of use drinking water. } \\
\text { Deals with the control of water pollution and maintenance of quality standards for drinking water. } \\
\text { Sets out the conditions of service utilization by consumers. } \\
\text { It provides for the acquisition of houses and land and compensation. } \\
\text { Establishes a decentralized governance structure }\end{array}$ \\
\hline 15. & $\begin{array}{l}\text { Local Self Governance Act } 1999 \\
\text { (2055BS) }\end{array}$ & $\begin{array}{l}\text { Sets out the powers, functions and duties of the VDC, Municipality and DDC in relation to water and } \\
\text { sanitation. } \\
\text { Sets out which natural resources are assets of local bodies and empowers local bodies to levy a natural } \\
\text { resource tax. }\end{array}$ \\
\hline 16. & $\begin{array}{l}\text { Local Self Governance } \\
\text { Regulation1999 (2056BS) }\end{array}$ & $\begin{array}{l}\text { Sets out the power, function and duties of VDC, Municipality and DDC in relation to water and sanitation. } \\
\text { Establishes the procedure for the formulation of the water related plan and project implementation. }\end{array}$ \\
\hline 17. & $\begin{array}{l}\text { Irrigation Regulation } 2000 \\
\text { (2056BS) }\end{array}$ & $\begin{array}{l}\text { Deals with Irrigation Water User Associations and the transfer of projects to Irrigation Water User } \\
\text { Associations. } \\
\text { Provides for a joint management system by HMGN and Irrigation Water User Association. } \\
\text { Deals with Irrigation and River Control Committee } \\
\text { Sets out the conditions of service utilisation. } \\
\text { Sets out the obligations of user of irrigation and provides for service charges. } \\
\text { Deals with the protection, repair and maintenance of irrigation systems. }\end{array}$ \\
\hline
\end{tabular}

(Source: Water Aid Nepal, 2005).

\section{Water Resources}

Nepal is the second richest country for water resources. There are five different types of water resource found in Nepal in the form of snow covers, rivers, springs, lakes and ground water. The renewable water resource of Nepal is approximately $237 \mathrm{Km}^{3}$ per year in which $225 \mathrm{~km}^{3}$ per year for surface water source and $12 \mathrm{~km}^{3}$ per year for ground water sources and the per capita of water availability were $9600 \mathrm{~m}^{3}$ per capita per year in 2001 [33]. The Kathmandu valley consists of two major aquifers which provide the drinking water to the local residents. They are Shallow Aquifer and Deep aquifer. The upper aquifer lies in $50 \mathrm{~m}$ depth which consists of inter bedded silt and clay with some irregularity specially in Patan and Thimi area [34]. The aquitard of $200 \mathrm{~m}$ thickness lies in the western part of the Kathmandu Valley which hold the upper aquifer and below this clay aquitard there is a deep aquifer which is used by the municipalities, hotels and private companies. There is the recharge of deep aquifer occurs in the north east part of this Kathmandu valley. The recharge rate is estimated from the range 13000 to $40000 \mathrm{~m}^{3} /$ day. But in average of 1095 to $3285 \mathrm{~m}^{3} /$ day is due to the current water extraction by Nepal Water Supply Corporation [35]. Now days the newly constructed building going on increasing day by day which cause the water spout found dry. Due to this building the deeper foundations becomes seal the flow of water from it and damage the channels during construction. The recharge of rain water from the ground and garden becomes seals. The ground water extraction and deep boring also cause the dry of water in the Dhunge Dhara. The expansion and construction of road also cause destruction of water channels which induce the dry out in Dhunge Dhara [36].

The Bacterial contamination, Heavy metal contamination and suitability of water in five different types of water resources of Kathmandu is shown in table (Table 2) [37].

Table 2. Bacterial contamination in Water resources.

\begin{tabular}{llll}
\hline Bacterial Contamination in the five types of water resources & & Coliform \\
\hline Source & No. of Samples & E. Coli & $100 \%$ \\
\hline Dug well & 37 & $86 \%$ & $100 \%$ \\
Shallow aquifer tube well & 38 & $55 \%$ & $94 \%$ \\
Municipal Sources & 19 & $76 \%$ & $100 \%$ \\
Dhunge Dhara & 16 & $73 \%$ & $100 \%$ \\
Deep aquifer tube well & 5 & $40 \%$ & \\
\hline
\end{tabular}

Source: (Hydrogeology Journal, 2008). 


\begin{tabular}{llll}
\hline Heavy metal Contamination in the five types of drinking water resources & & \\
\hline Source & No. of Samples & Arsenic $(\boldsymbol{\mu g} / \mathbf{L})$ & Mercury $(\boldsymbol{\mu g} / \mathbf{L})$ \\
\hline Dug well & 16 & $0 \%$ & $6.3 \%$ \\
Shallow aquifer tube well & 23 & $0 \%$ & $0 \%$ \\
Municipal Sources & 12 & $0 \%$ & $0 \%$ \\
Dhunge Dhara & 13 & $0 \%$ & $33 \%$ \\
Deep aquifer tube well & 6 & $50 \%$ & $0.7 \%$ \\
\hline
\end{tabular}

Source: (Hydrogeology Journal, 2008).

\begin{tabular}{llll}
\hline \multicolumn{4}{l}{ The number of samples above the limit was based on the WHO standard of $\mathbf{1 0}$ and $\mathbf{1}(\boldsymbol{\mu g} / \mathbf{L})$ for arsenic and mercury, respectively. } \\
\hline \multicolumn{2}{l}{ Comparison of water described as suitable for drinking and water described as not suitable for drinking } \\
\hline \multirow{2}{*}{ Source } & No of Samples & Perception & Not suitable for Drinking \\
\cline { 2 - 4 } & 2 & 1 & 1 \\
\hline Deep wells & 15 & 15 & 0 \\
Dhunge Dhara & 35 & 20 & 15 \\
Dug Wells & 36 & 14 & 22 \\
Shallow aquifer Tube Well & 3 & 3 & 0 \\
Municipal Sources & & 14 & \\
\hline
\end{tabular}

Source: (Hydrogeology Journal, 2008).

The water abstraction rate is different in different location of Nepal. It is presented in table (Table 3).

Table 3. Water abstraction rate in Nepal.

\begin{tabular}{lll}
\hline \multirow{2}{*}{ Institution } & \multicolumn{2}{l}{ Abstraction Rate (mld) } \\
\cline { 2 - 3 } & Year 2002 & Year 2009 \\
\hline KUKL & 42 & 36 \\
Government/Institutions & 5.36 & 10 \\
Tankers and Others & 5.37 & 30 \\
Hotels & 6.53 & 8 \\
Total & 59.26 & 84 (includes 13 from spring water) \\
\hline
\end{tabular}

Source: (WEPA, 2010).

The water abstraction rate in Kathmandu is increasing day by day from the KUKL, Government Institutions, Tankers, Hotels and Others.

\section{Some Legal and Regulatory Issues in Kathmandu Valley}

The present situation of groundwater extraction has raised several legal issues related to regulation and management of groundwater resources in Kathmandu valley. Some of them are highlighted below:

1. Drinking water is first priority use of any water resource in the country (Water Resources Act, 2049; section 7). According to this provision, municipal, community and household users of groundwater should get the highest priority over industrial or commercial uses, but increasingly large volume of groundwater is extracted from high capacity private deep tube wells that are operated by industrial and commercial establishments and are affecting the domestic users adversely (WRA, 2049; section 4.3). This poses a problem with the 'beneficial use of water' provision in the Act.

2. Drying up of traditional water supply sources such as Dhunge Dharas and natural springs have deprived the prior use right of the users of these traditional water sources (WRA, 2049; section4.3). Similarly, the small sized household well operators, who have the legitimate right over access to groundwater which occurs underneath their property, suffer because their wells become dysfunctional when the water table goes down below their well depth and pumping capacity (WRA, 2049 BS; section 4.2. e).

The Kathmandu Valley Water Supply Management Board, under the Water Supply

Management Board Act 2063 BS (2006) (Section 7. c) 18 has begun to issue license to deep tube well operators in the valley, irrespective of whether the extracted groundwater is used for drinking water or other purposes. Using well depth as criteria, license fee has been fixed at Rs. 10,000 for wells that have less than $100 \mathrm{~m}$ depth and Rs. 20,000 for those wells that are more than $100 \mathrm{~m}$ deep. The KVWSMB, at the moment, has not decided whether this fee will be collected on an annual basis or it will a one-time registration fee. The KVWSMV has issued license to KUKL for operating 78 Tube wells that were handed over by the Nepal Water Supply Corporation (NWSC) under the management contract between KVWSMV and KUKL. The KUKL pays an annual fee to KVWSMB as per the agreement, but there is no clear cut distinction of whether the fee is for utilizing the (ground) water resource or for utilizing the pre-existing water supply infrastructures [38].

\section{Disaster Resilient Construction}

The water insecurity, poor sanitation and hygiene are the main problem of less developed countries which causes the imbalance between the supply and demand of water. The urbanization increases the possibility of water related disaster because water, sanitation and hygiene system are imperfectly designed, applied and maintained in such cities [39]. As WASH system contains a fundamental human need which is 
the major driver for economic development. The ability of managing the good water resource can support productivity across economic sectors and also contribute to the health of ecosystem [40]. The failure of water service resilient in case of natural and human made hazards may cause the negative impact on public health and happiness. The recent studies focused on the challenges and suggest the recommendations for improvement of technology and development of institution for the long term resilience of water and sanitation system [41]. Moreover, the natural hazards obstruct the human development which causes poverty. The improvement of the resilience of urban WASH system is the main key for the national security issue of sustainable development [42]. The Kathmandu valley is a disaster prone area which now facing the chronic water insecurity due to the urbanization [43]. The earth quake also obstructed the pre- existing WASH system in this valley. The massive disasters can cause the water related disease epidemics [44].

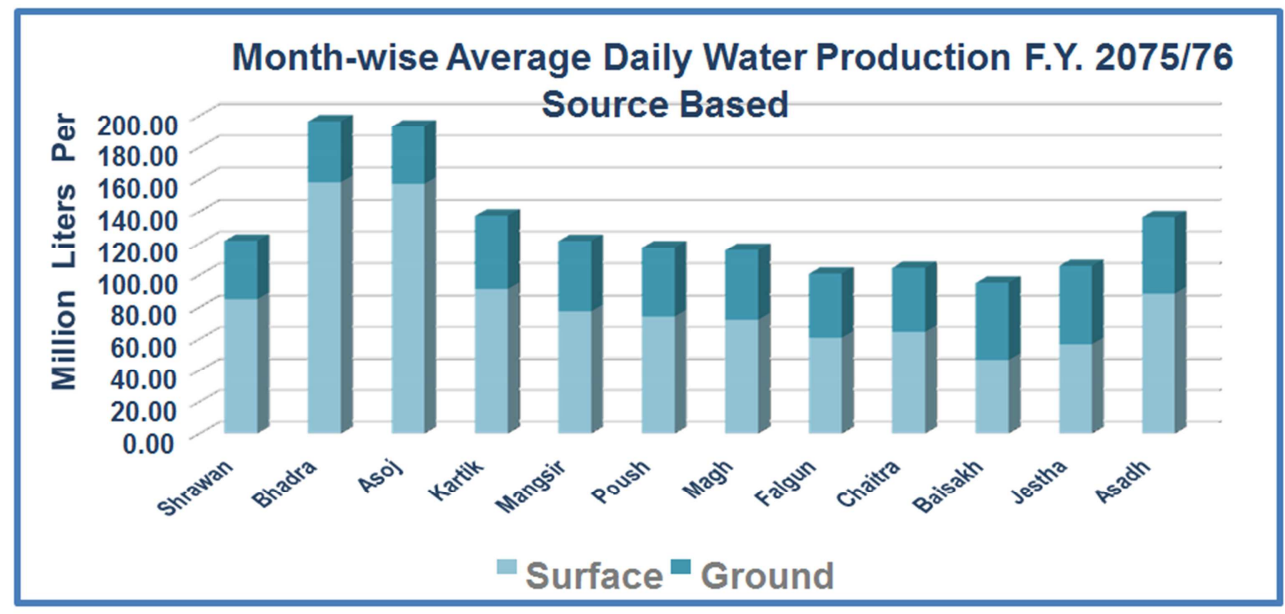

Source: (KUKL, 2020).

Figure 1. Daily water production of $K U K L$.

Different disciplines use different definitions of resilience. In the context of social systems, resilience has been defined as 'the ability of a system, community, or society exposed to hazards to resist, absorb, accommodate to and recover from the efforts of a hazard in a timely and efficient manner' [45]. The study shows that $60 \%$ of the households recognize 'resilience' in their water system after the massive earthquake. The households with their own wells or with piped water had more resilient water systems. The further study is needed to evaluate the discrepancy in resilience to natural disasters according to socio- economic status. The urban water supply policy and disaster plan should be developed by government and policy makers to increase their resilience during chronic water shortages [46].

The indigenous water management system (IWMS) carries out in Bhaktapur city of Nepal. The traditional water system was efficient and rational in terms of cascaded water use and water harvesting system. It is conveyance and reusability practices for the historical settlement. The study highlights that revitalization of IWMS is possible in Bhaktapur city [47].

\section{Problem and Response on Water Resources}

\subsection{Global Problem and Response on Water Resources}

About $71 \%$ of the surface of Earth is covered by water and $96.5 \%$ of earth water is in the form of oceans as a saline. The $68 \%$ of total fresh water is in the form of ice and glaciers, $30 \%$ of freshwater is in the form of ground water and only $1 \%$ of water is fresh surface water that people used from the Rivers [48]. There are about $66 \%$ of the peoples in U. S. used surface water system where as $34 \%$ of the Peoples use ground water supply system [49]. There are enough water resources in South America both per capita and per area. However, the water scarcity is increasing rapidly by increasing urbanization and rapid economic growth due to high water demanding industries for example mining and agriculture. Water scarcity, Pollution, the affordability of water to the poorest and retiring workforce is the major issues that affect drinking water supply and sanitation in the USA. Water conservation begins with the help of federal water sense program. The reuse of wastewater treatment is also increased. The wastewater discharge pollution is also largely under control. The water consumption rate is double in United States then the central Europe. Water resource development, Structural flood control, and Centralized drinking and wastewater treatment are the major challenges which are face by the water resources manager of USA in $20^{\text {th }}$ century. But now they focus on the management of land uses for the prevention of ground water contamination and polluted runoff, restoration of aquatic ecosystems and promotion of delivery of ecosystem services [50].

In Denmark, the contingent valuation survey approach is used for the water quality improvements. The implementation of recent water quality legislation by European Union is addressing the potential problem in Eutrophication of estuarine and coastal waters. They have action plan for improvement of ecological status of the Randers Fjord for benefits and cost of reduced eutrophication 
of it [51].

In the South Africa too there are ground water drought issues. The drought-relief drilling programs, the general lack of routine monitoring and the need for longer term analysis and assessment of groundwater systems are the major difficulties in South Africa [52].

The China is also facing the strategic issue in the national sustainable development due to the climate change and its impact on water resources security. The research in climate change and its impact on water cycle gives the relation between the climate change and water science. The limited water resources and the climate change influence the challenge and opportunity too. The water cycle components give the quantitative analysis and prediction of the uncertainties in the hydrological events. The study of the water resources vulnerability and secure the water resources security is two important tools [53]. In the future, the utilization ratio of canal system and farmland water by using scientific and technological tools which help to increase the water use ratio, management, conservation of water resources and environment and increase the study of water saving techniques [54].

In India also due to the unplanned development of surface and groundwater resources, haphazard disposal of municipal and industrial wastes and application of agricultural inputs induced the water quality deterioration, problem in water management and preservation. The agro climate and the hydrological cycle has been changed due to the human activities of India such as cropping pattern, land use pattern, irrigation and drainage [55].

Although Australia is a continent of extreme water resources the people of tropical north relative abundance whereas the people of south have relative scarcity of water resources in addition both are affected by wet and dry seasonal climatic conditions. In south over allocation of surface and ground water supplies and increase use of water from irrigators, urban, industrial and mining users which impacts on the health of rivers and environments [56].

\subsection{Regional Problem on Water Resources}

Nepal is one of the most plentiful water supply country and then Bhutan along with the Maldives are the three least developed countries in the Asian region but the facilities of safe drinking water and for excreta disposal can be woefully inadequate [57]. There is the international monitoring system of drinking water and sanitation which gives the awareness of needs, informs policy, implementation and research to improve services. The Millennium Development Goals targets for it globally to reduce the global disease burden and improve the quality of life. The MDG gives the information about the strengths and limitations to defining the monitoring access to it. WHO and UNICEF both give the Joint Monitoring Program to analyze the data from household survey and linear regression modeling over time which gives the nationally and internationally comparable insights in to drinking water and sanitations facilities. This method does not focus on the water quality of water and equity of access but gives information of impact and future direction towards the international monitoring of drinking water and sanitation [58]. About 1.1billions people in this world are suffer from safe drinking water. About 400 deaths of children below the age of 5 years hourly is due to the biological contamination of drinking water. The review must be done for general guidelines and global problem of drinking water quality and various water treatment technologies which is applicable for increasing the quality of drinking water in the developing countries [59].

The government of Maldives need of a supplementary water supply system due to huge tsunami on 2004 for 46 islands through the provision of sea water, Desalination and Reverse Osmosis Plants. About 90\% of household's water is dependent on rain water as a principal source of drinking water and $30 \%$ of population induced from the drinking water scarcity [60].

In the rural north east Thailand, the most villagers carry water and store it in separate containers for household work like toilet, washing dishes and cooking. The water contaminated with fecal bacteria is due to cross contamination and water handling mechanism of stored water pollution which is used to develop a hygiene intervention study [61].

In Southwest Sri Lanka, the safe source of water considered is piped network supplies, public taps, and private wells. About $72 \%$ of households consider public taps to be safe, some on public wells, rivers, lakes and streams. The test of water and cleanness is satisfactory in private connections, public taps, neighbors, private wells and vendors are satisfactory. Most of the households used water after boiling or filtering water before drinking it in Sri Lanka [62].

\subsection{National Problem on Water Resources}

Due to the poor infrastructure and high population growth rate in Nepal, there is a challenging to achieve the six targets of United National Sustainable Development Goal of water and sanitation for all people. There is the estimated available water resources and domestic water demand in Kathmandu valley that is 102 million liters per day in 2016 after completion of the first phase of Melamchi Water Supply Project. If the project is completed in a time, there would be no water deficit by 2023-2025. This shows that the project makes the significant contribution to the valley's water security. there is the mitigation option too such as rain water harvesting, use of ground and surface water resources and water demand side management [63].

From the data of UNICEF about 10.8 million people in Nepal have lack of improve sanitation and 3.5 million unable to access the basic water services. Nepal have improved significant progresses in expanding access to water and sanitation over the last few decades and adopted lots of challenges such as poverty, difficult terrains and conflicts. There is $71 \%$ of all water sources having poor water quality and $91 \%$ of water used by the poorest quintile have contaminated by E-coli bacteria. Only $25 \%$ of water supply is fully functioning [64]. 
After the huge earth quake in Nepal, there is challenging of repair water system. Almost half of the water system destroyed by earthquake due to which leaving many people with no access of drinking water for two months. The water system and networks of Kathmandu valley destroyed and dried up water sources across 14 districts by it which causes Rs 210 million worth of damage to drinking water projects in valley by the preliminary assessment report of Upatyaka Khanepani Limited (KUKL). Before the earthquake also people inside the valley faced chronic water shortage with the demand of 85 million liters per day. In Kathmandu valley, total 11318 water projects running in which 4530 projects damages and 945 projects ceased due to earthquake. The worst damage recorded in Sindhuli, Sindhupalchowk and Kavre [65].

Lakuribhanjyang lies in the Lalitpur District which is $22 \mathrm{~km}$ from Kathmandu which consists of vulnerable Tamang group. The Earthquake affects the village and their water source and supply destroyed, the women and girls walks for water by foot which is not safe to drink. There is lack of awareness and water shortage. FRANK provides the safe water for 25 households in Lakuribhanjyang which lies at the top of the ridge. The NGO Partner repair the old water pipeline, rebuild the spring source and after then made distribution tank to 25 households for the source of safe drinking water. It works with the community to increase the awareness of risk carried out by the dirty water, poor hygiene practices and open defecation to minimize the risk [66]. Siddhipur Water Treatment Plant (SWTP) lies in Lalitpur funded by UN-HABITAT, Water Aid and Environment and Public Health Organization (ENPHO) whose main aim is the regulation of drinking water with the proper treatment. It can treat the water from Godavari River by using the tube settler, slow sand filter and chlorination technology. After that it is provided to 1350 households in the communities [67].

Most of the water resources in Bhaktapur are used for commercial purpose. There are various commercial water supplier companies in the place which distribute water in the form of mineral water, jar water and tank water due to which the locals are not access to drinking water. There is the lack of proper reservation and distribution system of drinking water in Bhaktapur. KUKL unable to reserve and lay pipeline for drinking water distribution. There are several small projects made by locals for drinking water but are not well managed. There is the World Vision Bhaktapur ADP which supports the drinking water project for 532 households. The project completed with the involvement of local's partnership with local NGO, ARSOW Nepal. They formed a local Water Users Committee for the maintenance of the drinking water collection and distribution which collect NRS60 per month as a maintenance fund for ensuring the system [68].

In every year of monsoon, the residents of Pokhara facing the murky drinking water. They demand the water treatment plant from Nepal Water Corporation for the past 30 years for clean drinking water. With the help of Japan government, they have to set up the water purification plant in Pokhara will be completed in four years. The people are force to buy the water from the commercial water supplier company due to the water mixed with sand and mud run through the 39000 taps in the city. Nepal Water Corporation brought water from Mardi River and collects it in a tank at Bindhyabasini before distribution to the consumers. It supplies about four crore liter of water to the locals from the Mardi River per day but the requirement is five crore liter water per day. The pipeline expansion project has been stopped due to the lack of funds. It started to works for installing DI pipes in Pokhara to address the increasing need for drinking water in the city [69].

\subsection{Local Problem on Water Resources}

Nepal is standing among the top ones in terms of water resource globally. Unfortunately, the water scarcity problem is a major issue. The population of the Kathmandu valley increases day by day at the rate of $4.7 \%$. The daily water demand is 360 million liters per day but the capacity of supply is only 90 million liters per day in dry season where as 140 million liters per day in wet season. Now a day $70 \%$ households in Kathmandu valley use tap water as a primary source of water where as $14 \%$ of households use the tanker water as a primary water source by paying a premium price of around $15 \%$ to tanker water compared to the tap water source. The extraction of ground water started in Kathmandu since 1970s and since then the extraction rate increasing day by day. The expert says if the ground water is extracted in such rater there will be no ground water after 100 years. The research data determine that $80 \%$ of tap water contains coli bacteria which is unsuitable for drinking directly and in well and boring water, there is iron and turbidity which make water unsuitable for drinking and cooking. The Melamchi water project is hope for resort water crisis in Kathmandu valley [70].

Kathmandu Upatyaka Khanepani Limited (KUKL) is the main company which can undertake and manage the water supply and sanitation system in Kathmandu valley. It provides the quantitative, qualitative and reliable service to its customer at reliable price. It is also responsible for operation and management of drinking water supply and wastewater services. Melamchi Water Supply Project works under this company to solve water scarcity problem in Kathmandu valley. KUKL has 10 Branch Offices for production and operation of drinking water supply among which Tripureshwor Branch Supply the drinking water in Kathmandu Municipality and Nagarjun Municipality whereas the Lalitpur Branch Supply the drinking water in Karyabinayak, Mahalaxmi, Goidawari and Lalitpur Sub metropolitan city [71].

\section{Conclusions}

The study was focused only on the recent status of Hiti. It found that the population of Kathmandu and Lalitpur is increasing rapidly but the source of drinking water is decreasing gradually. In the past, Dhunge Dhara was feeding the communities for drinking water as there are all together 237 Dhunge Dhara in Kathmandu and Lalitpur area. In the Kathmandu Valley, the source of water spouts decline is due 
to the development of various engineering infrastructures such as roads, buildings, towers, and so on. Similarly, rapid growth of urbanization took place near the source of water spouts. As a result, there could not be the chance of ground water recharge. The water from the rainfall flows directly through the waste pipe to the river. In the past, there were irrigation canals called Rajkulo, these canals effectively recharged the ground water. As the valley is converted into the city of concrete, it causes stoppage of ground water recharge near the hiti. Consequently, there is no water in the water spouts i.e. in Dhunge Dhara. The study would like to suggest that the traditional Dhunge Dhara in the valley must be preserved through the initiation of the local, provincial and central government.

\section{References}

[1] USGS, "The Fundamentals of the Water Cycle," 2018. https://www.usgs.gov/special-topic/water-science-school.

[2] H. Mifflin, "Rainwater definition and meaning | Collins English Dictionary," 2010.

[3] IWA Publishing, "Rainwater," 2016. https://www.iwapublishing.com/news/rainwater-why-it-safe

[4] R. Becker, "Water Conduits in the Kathmandu Valley, 2 Vols. by Raimund O. A. Becker-Ritterspach: New Hard Cover (1995) First Edition. | Vikram Jain Books," 1995. https://www.abebooks.com/first-edition/Water-ConduitsKathmandu-Valley-2-Vols/22855612365/bd.

[5] UHN, "Water Movement in Patan: With reference to Traditional Stone Spout in Nepal | UNHabitat," 2007. $\mathrm{http}$ //unhabitat.org.np/?publications=water-movement-inpatan-with-reference-to-traditional-stone-spout-in-nepal.

[6] NGOFUWS, "Homepage | WASH Matters," 2006. https://washmatters.wateraid.org/.

[7] P. R. Joshi, "Feasibility Study of Rajkulo: Rehabilitation of Patan's Traditional Water Supply Network, Final Report: Patan Conservation and Development Programme.," UDLE/GTZ, 1993.

[8] H. R. Joshi and S. D. Shrestha, "Feasibility of recharging aquifer through rainwater in Patan," Bulletin of the Department of Geology, Tribhuvan University, 2008.

[9] M. D. Acharya, "Progress of Water Environment Governance in Nepal," p. 24, 2019.

[10] UNISDR, "the capacity of a system, community or society potentially exposed to hazards to adapt, by resisting or changing in order to reach and maintain an acceptable level of functioning and structure," Hyogo Framework of Action, 2005.

[11] N. Vista, "Nepal Bureau of Standards, Weather MeteorologyNepal Bureau of Standards, Weather Meteorology," 2009.

[12] Lukinbeal, "Traditional Infrastructure, Modern Flows: Cultural Politics of Development in the Kathmandu Valley, Nepal," Association of Pacific Coast Geographies, 2014, http://apcgweb.org/sites/default/files/editor_uploads/files/pacif icaf14.pdf.
[13] R. Shrestha, "Bhaktapur Nagar ma Dhunge Dhara ko Aitihasik Mahatwo," Bhaktapur Campus, M. A, 1984.

[14] R. Pradhan, "Dhunge Dhara: A Case Study of the Three Cities of Kathmandu Valley," pp. 10-14, 1990.

[15] G. Khaniya, "Traditional Water Management Practices. A Case Study Of Bhaktapur City," 2005.

[16] M. Aryal, "Reviving Patans royal canal," Nepali Times, 2005.

[17] UHN, "Traditional Water management and Machhendranath Festival.," 2019.

[18] O. A. Raimund and R. Becker, "Water Conduits in the Kathmandu Valley,” 1995.

[19] M. Tripathi, "A comparative evaluation of stone spout management systems in heritage and non-heritage areas of Kathmandu Valley, Nepal," Thesis, Lincoln University, 2016.

[20] Padma Sunder Joshi, "Traditional Ponds-The Water Urbanism of Newar Civilization," 2018.

[21] S. Phuyal, "The women of Bhajya Pukhu," 2018.

[22] P. Khatri, "Kathmandu water spouts, lost and found cases." 2019.

[23] GNME, "Government of Nepal Ministry of Environment, Science and Technology Final Report Historical and Environmental Study of Rani Pokhari Submitted,” 2012.

[24] S. R. Tiwari, "The Pit Conduit Water Supply System of Kathmandu," 2016.

[25] S. Shrestha, "Dhungedhara: A Nepali Technology to Supply Water," 2015.

[26] Hiti Manga, "Hiti Manga-The Mythical Creature," 2018.

[27] A. Joshi, "Off the deep end," Kathmandu Post, 2017.

[28] A. Snyde, "Shortage in the Mountains of Plenty: Water Supply in Mountain and Hill Cities throughout the HinduKush Himalayan Region," Borlaug-Ruan International Internship, ICIMOD, Lalitpur, Nepal and The World Food Prize Foundation, Des Moines, Iowa, 2014.

[29] S. Koirala, "Study of Architecture Style and Construction Technologies of Public Rest House-Pati with Discusssion of Case-MATAYA PHALCHA," Department of Architecture, Tribhuvan University, Kathmandu, 2018.

[30] R. Becker and O. A. Raimund, "Dhunge-Dharas in the Kathmandu Valley. Continuity and Development of Architectural Design," Ancient Nepal, 1996.

[31] Rits-DMUCH, "Disaster Risk Management for the Historic City of Patan, Nepal," Ritsumeikan University, Kyoto, Japan and Institute of Engineering, Tribhuvan University, Kathmandu, Nepal, 2012.

[32] Water Aid Nepal, "Water Laws in Nepal Laws Relating to Drinking Water, Sanitation, Irrigation, Hydropower and Water Pollution."2005.

[33] WEPA, "State of water: Nepal," 2010. http://www.wepadb.net/policies/state/nepal/state.htm.

[34] M. Yoshida and Y. Igarashi, "Neogene to Quateernary lacustrine sediments in the Kathmandu Valley, Nepal," $J$ Nepal Geol Soc, vol. 4, pp. 73-100, 1984. 
[35] M. Jha, M. Khadka, and M. Shrestha, "The assessment of ground water pollution in the Kathmandu Valley, Nepal: report on Joint Nepal-Australia Project 1995-96," Australian Geological Survey Organisation, Canberra, pp. 1-64, 1997.

[36] S. Khadge and S. R. Tiwari, "Conservation of Water Heritage in Kathmandu Metropolitan City," In Proceedings of IOE Graduate Conference, pp. 452-460, 2014.

[37] N. R. Warner, J. Levy, K. S. Harpp and F. T. Farruggia, "Drinking water quality in Nepal's Kathmandu Valley: A survey and assessment of selected controlling site characteristics", Hydrogeology Journal, 16 (2): 321-334, 2008

[38] D. R. Kansakar, "regulating common pool groundwater under fugitive surface water law: limitations in laws and regulations in nepal," Jalsrot Vikas Sanstha/ Global Water Partnership Nepal, p. 36, 2011.

[39] Å. Johannessen and C. Wamsler, "What does resilience mean for urban water services?” $E \& S$, vol. 22, no. 1, p. art1, 2017, doi: $10.5751 / \mathrm{ES}-08870-220101$.

[40] Stockholm International Water Institute, "Making Water a Part of Economic Development: The Economic Benefits of Improved Water Management and Services-Stockholm International Water Institute," 2005. https://www.siwi.org/publications/making-water-a-part-ofeconomic-development-the-economic-benefits-of-improvedwater-management-and-services.

[41] G. Howard and J. Bartram, "The resilience of water supply and sanitation in the face of climate change," WHO, 2010.

[42] C. Wamsler, "Cities, Disaster Risk and Adaptation," 2014. https://www.amazon.com/Disaster-Adaptation-RoutledgeCritical-Introductions/dp/0415591031.

[43] N. R. Khatiwada, S. Takizawa, T. V. N. Tran, and M. Inoue, "Groundwater contamination assessment for sustainable water supply in Kathmandu Valley, Nepal," Water Science and Technology, vol. 46, no. 9, pp. 147-154, 2002, doi: 10.2166/wst.2002.0226.

[44] M. Ahern, R. S. Kovats, P. Wilkinson, R. Few, and F. Matthies, "Global Health Impacts of Floods: Epidemiologic Evidence," Epidemiologic Reviews, vol. 27, no. 1, pp. 36-46, 2005, doi: 10.1093/epirev/mxi004.

[45] UNOFDRR, "UNISDR Terminology on Disaster Risk Reduction," 2009 http://www.unisdr.org/we/inform/publications/7817.

[46] Y. Aihara et al., "Resilience in household water systems and quality of life after the earthquake: a mixed-methods study in urban Nepal," Water Policy, vol. 20, no. 5, pp. 1013-1026, 2018, doi: $10.2166 / \mathrm{wp} .2018 .117$.

[47] D. Gautam, B. R. Thapa, and R. N. Prajapati, "Indigenous water management system in Nepal: cultural dimensions of ater distribution, cascaded reuse and harvesting in Bhaktapur City," Environ Dev Sustain, 2017.

[48] H. Peter, "Water in Crisis: A Guide to the World's Fresh Water Resources," Oxford University Press, New York), 1993.

[49] EPA, "Water on Tap: What You Need to Know," 2009, https://nepis.epa.gov.

[50] C. Lant, "Watershed Governance in the United States: The Challenges Ahead," UNIVERSITIES COUNCIL ON WATER
RESOURCES, no. 126, pp. 21-28, 2003.

[51] J. P. Atkins and D. Burdon, "An initial economic evaluation of water quality improvements in the Randers Fjord, Denmark," Marine Pollution Bulletin, vol. 53, no. 1, pp. 195204, Jan. 2006, doi: 10.1016/j.marpolbul.2005.09.024.

[52] R. C. Calow et al., "Groundwater Management in Droughtprone Areas of Africa," International Journal of Water Resources Development, vol. 13, no. 2, pp. 241-262, Jun. 1997, doi: 10.1080/07900629749863.

[53] X. Jun, L. Chunzhen, and R. Guoyu, "Opportunity and Challenge of the Climate Change Impact on the Water Resource of China-- 2011. http://en.cnki.com.cn/Article_en/CJFDTotalDXJZ201101000.htm.

[54] Q. Feng, G. D. Cheng, and M. K. Masao, "Trends of water resource development and utilization in arid north-west China," Environmental Geology, vol. 39, no. 8, pp. 831-838, Jun. 2000, doi: $10.1007 / \mathrm{s} 002549900062$.

[55] R. K. Mall, R. Bhatla, and S. N. Pandey, "WATER RESOURCES IN INDIA AND IMPACT OF CLIMATE CHANGE," Jalvigyan Sameeksha, vol. 22, 2007.

[56] C. Chartres and J. Williams, "Can Australia Overcome its Water Scarcity Problems?" Journal of Developments in Sustainable Agriculture, vol. 1, pp. 17-24, 2006.

[57] U. R. Nath, "The cost of water," Springer, vol. 3, pp. 295-298, 1983.

[58] J. Bartram, C. Brocklehurst, and B. Gordon, "Global Monitoring of Water Supply and Sanitation: History, Methods and Future Challenges," vol. 11, p. 8, 2014.

[59] A. Gadgil, "DRINKING WATER IN DEVELOPING COUNTRIES," Annual Review of Energy and the Environment, vol. 23, no. 253-286, 1998, https://doi.org/10.1146/annurev.energy.23.1.253.

[60] UNDP, "Developing a Disaster Risk Profile for Maldives," RMSI, vol. $\quad 1$, 2006, https://www.preventionweb.net/files/11145_MaldivesDisaster RiskProfileFinalRep.pdf.

[61] J. V. Pinfold, "Faecal contamination of water and fingertiprinses as a method for evaluating the effect of low-cost water supply and sanitation activities on faeco-oral disease transmission. I. A case study in rural north-east Thailand," Cambridge University Press, vol. 105, no. 2, pp. 363-375, 2009.

[62] C. Nauges and C. Van Den Berg, "Perception of Health Risk and Averting Behavior: An Analysis of Household Water Consumption in Southwest Sri Lanka," Toulouse capitole Publications, vol. 9, p. 139, 2009.

[63] P. Udmale, H. Ishidaira, and N. M. Shakya, "The Status of Domestic Water Demand: Supply Deficit in the Kathmandu Valley, Nepal," MDPI, 2016, www.mdpi.com.

[64] UNICEF, "Water and Sanitation (WASH)," 2015, https://www.unicef.org/nepal/water-and-sanitation-wash.

[65] R. Rai, "Nepal struggles to repair water systems destroyed by quake," The third pole.net, 2015, https://www.thethirdpole.net/2015/07/14/nepal-struggles-torepair-water-systems-destroyed-by-quake/. 
[66] FRANK Water, "FRANK Water In Lalitpur, Nepal,” 2010.

[67] C. Visvanathan, "NewTap |Network on Water Technology in Asia and Pacific.," 2007, http://www.jwrcet.or.jp/aswin/en/newtap/report/NewTap_027.pdf.

[68] World Vision International, "Drinking Water Project, Bhaktapur," World Vision International, 2010.
[69] D. BASNET, "Drinking water pipeline expansion halted in Pokhara," The New York Times Partner, 2018.

[70] B. R. Manandhar, "The water situation in Kathmandu Valley," 2016.

[71] KUKL, "Kathmandu Upatyaka Khanepani Limited, Annual Report.” Annual report, 2020. 